TITLE:

\title{
Effects of combination between web density and size of spider mite on predation by a generalist and a specialist phytoseiid mite.
}

$\operatorname{AUTHOR}(S)$ :

Iwasa, Takuya; Osakabe, Masahiro

\section{CITATION:}

Iwasa, Takuya ...[et al]. Effects of combination between web density and size of spider mite on predation by a generalist and a specialist phytoseiid mite.. Experimental \& applied acarology 2015, 66(2): 219-225

ISSUE DATE:

2015-04-10

URL:

http://hdl.handle.net/2433/198653

\section{RIGHT:}

The final publication is available at Springer via http://dx.doi.org/10.1007/s10493-0159902-7.; 許諾条件により本文ファイルは2016-04-10に公開.; この論文は出版社版でありま せん。引用の際には出版社版をご確認ご利用ください。; This is not the published version. Please cite only the published version. 
1 Experimental and Applied Acarology. 66(2), 219-225 (2015)

2

3

4

5 Effects of combination between web density and size of spider mite on predation by a generalist and a

$6 \quad$ specialist phytoseiid mite

7

8

9 Takuya Iwasa and Masahiro Osakabe

10

11 Laboratory of Ecological Information, Graduate School of Agriculture, Kyoto University, Kyoto

12 606-8502, Japan

13

14 


\section{Abstract}

16

17 Complicated three-dimensional webs of silk threads produced by Tetranychus spider mites provide

18 protection from predation by many generalist phytoseiid mite species. Accessibility to prey may be

19 the most significant criterion for successful predation in complicated webs. To assess the

20 protective effects of combination between web size and density, we compared predation on eggs of the

21 two-spotted spider mite, Tetranychus urticae, by a generalist (Euseius sojaensis) and a specialist

22 (Neoseiulus womersleyi) phytoseiid mite in the laboratory under manipulated web size and density. Web

23 sizes negatively affected to the predation. Significant interactions were found between phytoseiid mite

24 species and prey distribution; egg consumption by E. sojaensis was more in uniform distribution, but that

25 by $N$. womersleyi, in contrast, was larger in contagious distribution. However, the egg consumption by $E$.

26 sojaensis and $N$. womersleyi were both mitigated in larger webs. This area size depending mitigation was

27 more effective to the predation by $E$. sojaensis. Although the mechanism of web size depending

28 mitigation is unknown, web sizes might affect prey searching efficiency of this phytoseiid mite.

29 Consequently, combination between web density and size are likely to affect not only a generalist $E$.

$30 \quad$ sojaensis but also a specialist $N$. wormersleyi.

32 Keywords: Web size, Web density, Euseius sojaensis, Neoseiulus womersleyi, Tetranychidae,

33 Phytoseiidae 


\section{Introduction}

Tetranychus spider mites (Acari: Tetranychidae) produce complicated three-dimensional silk webs, on which they deposit eggs, fecal pellets, and cast skins (Saito 1983). These webs provide refuge from predation by generalist phytoseiid mites by impeding and entangling them (McMurtry and Scriven 1964, McMurtry and Johnson 1965, Osakabe 1988). Tetranychus spider mites usually spin silk threads as they walk (Saito 1983). Therefore, larger groups of individuals construct denser, more complex webs that may confer greater protection from generalist phytoseiid mites. However, webs also provide a prominent prey-searching cue for specialist phytoseiid mites (Hislop and Prokopy 1981, Hoy and Smilanick 1981, Sabelis et al. 1984, Furuichi et al. 2005, Yano and Osakabe 2009, Shinmen et al. 2010).

Accessibility to prey (i.e., capacity to penetrate complicated webs) may be the most significant criterion for successful predation by phytoseiid mites in complicated webs produced by Tetranychus spider mites (Sabelis and Bakker 1992, Shimoda et al. 2009). Euseius sojaensis Ehara (Acari: Phytoseiidae) is a generalist phytoseiid mite (Type IV; McMurtry and Croft 1997) incapable of penetrating complicated webs (Osakabe et al. 1986, 1987; Osakabe 1988). However, Ozawa and Yano (2009) pointed out that although prey is inaccessible after the web is completely constructed, E. sojaensis can prey on Tetranychus mites at the beginning of colonization. Moreover, Yano (2012) showed that increasing the interval between the start of Tetranychus spider mite colonization and prey searching by $E$. sojaensis significantly mitigated predation. Accumulation of webs during this interval may provide better protection, whereas the protective function of sparse webs may be insufficient even against a generalist phytoseiid mite. Although examinations of this relationship usually assume that spider mites and their eggs are distributed throughout their webs, predation risk to eggs may be higher if those are distributed near the web's edge. In this context, predation risk would be higher when the webbing area is smaller. However, the protective effects of combination between web density and size have not been addressed virtually.

To assess the protective effects of combination between web size and density, we compared predation on eggs of the two-spotted spider mite, Tetranychus urticae Koch (Acari: Tetranychidae), by E. sojaensis and Neoseiulus womersleyi (Schicha) (Acari: Phytoseiidae) in the laboratory under manipulated webbing area size and aggregation of adult females involving prey egg distribution and also web density in the area. 


\section{Materials and methods}

Mites

Neoseiulus womersleyi were collected from roses (Rosaceae) in Nara, Japan and reared on T. urticae on kidney bean, Phaseolus vulgaris L. (Leguminosae), leaves placed on water-soaked cotton in Petri dishes (9 $\mathrm{cm}$ in diameter). Euseius sojaensis were collected from kudzu vines Pueraria lobota (Willd) Ohwi urticae (the yellow-green type) from several different localities in Japan and cultured on potted kidney bean plants has been established in our laboratory for more than 7 years. This was also reared on kidney bean leaves on water-soaked cotton in Petri dishes for several generations before use in the experiments. humidity (RH), with a photoperiod of 16L8D. All experiments were conducted under the same conditions as rearing. We used 2 to 3-day-old mated females of T. urticae, $N$. womersleyi, and E. sojaensis in all experiments.

Experimental design

We prepared $10 \times 10$-mm or $15 \times 15$-mm leaf squares cut from kidney bean leaves, excluding the main vein, as experimental patches. We pressed four $(10 \mathrm{~mm})$ or two $(15 \mathrm{~mm})$ leaf squares onto water soaked cotton in each Petri dish ( $9 \mathrm{~cm}$ in diameter). We put two wet cotton threads on each leaf square to divide it into four experimental quadrats. Four T. urticae females were then introduced individually into each quadrat (uniform distribution; Fig. 1a) or together into one quadrat (contagious distribution; Fig.1b) in a leaf square. 
and wet cotton threads so as not to destroy the webs. An adult female of E. sojaensis or $N$. womersleyi was introduced at the center of each leaf square. To ensure they were in a uniformly starved condition, the phytoseiid mites were kept individually in 1.5 -ml sample tubes with a water droplet for $48 \mathrm{~h}$ before the experiments. After $24 \mathrm{~h}$, we recorded the number of T. urticae eggs consumed. If a phytoseiid mite escaped from the leaf square during an experiment, the data were excluded from the following analyses. The area covered by complicated webs was in direct proportion to the area walked by T. urticae females, which ranged from 50 to $100 \mathrm{~mm}^{2}$ over $10-90 \mathrm{~min}$ in a laboratory experiment by Saito (1977). In our experiments, $T$. urticae adult females were allowed to walk freely in a $25-\mathrm{mm}^{2}$ (in the case of the 10-mm square) or $56.25-\mathrm{mm}^{2}$ ( $15-\mathrm{mm}$ square) quadrat for $24 \mathrm{~h}$. Therefore, quadrat sizes roughly corresponded to the area of complicated webs produced by T. urticae.

Replications (leaf squares) of uniform and contagious distributions against E. sojaensis numbered 15 and 12 , respectively, for 10-mm squares and 11 and 12 , respectively, for $15-\mathrm{mm}$ squares. Replications of uniform and contagious distributions against $N$. womersleyi numbered 16 and 8 , respectively, for 10-mm squares, and 20 and 16 , respectively, for 15 -mm squares.

Data analysis

We compared the numbers of eggs deposited in leaf squares among square sizes and distributions of introduced T. urticae females using a Wald test in a generalized linear model (GLM; Poisson error). Effects of area sizes and distribution of prey eggs on egg consumption by phytoseiid mites were analyzed using a linear model. Prior to this analysis, proportion of eggs consumed by phytoseiid mites were transformed to empirical logit. All analyses were conducted in R v. 2.15.2 (R Core Development Team 2012).

\section{Results}

The number of eggs produced by four T. urticae females ranged from 42 to 56 (Table 1), and more on 15-mm than on 10-mm squares (Table $2 \mathrm{~A}$ ). The distribution pattern of T. urticae females also significantly affected egg production: more in uniform than contagious distribution (Table $2 \mathrm{D}$ ). 
No significant difference was detected in prey egg consumption between phytoseiid mite species

123 (Table $3 \mathrm{P}$ ). Whereas, the area sizes negatively affected to the predation; egg predation rate was larger on

124 10-mm leaf squares than 15-mm leaf squares (Fig. 2, Table $3 \mathrm{~A}$ ), and this trend was clear in E. sojaensis in comparison with $N$. womersleyi (Tanble $3 \mathrm{P} \times \mathrm{A}$ ). Effects of prey distribution on egg consumption were marginal (Table 3 D). However, egg consumption by E. sojaensis decreased in contagious distribution of prey in comparison with uniform distribution on 10-mm leaf squares, but that by $N$. womersleyi, in contrast, increased in contagious distribution (Fig. 2, Table $3 \mathrm{P} \times \mathrm{D}$ ). No interaction was detected between leaf size and distribution of prey eggs (Table $3 \mathrm{~A} \times \mathrm{D})$.

\section{Discussion}

133 The egg consumption rates demonstrate opposite effects of aggregation of prey eggs to predation by $E$. sojaensis and $N$. womersleyi in smaller area (10-mm squares). Contagious distribution decreased predation by E. sojaensis, indicating that dense webs produced by aggregated females increased protection effects. This may reflect weakness of E. sojaensis to complicated webs of Tetranychus mites (Osakabe et al. 1986, 1987; Osakabe 1988). In contrast, predation by N. womersleyi increased in contagious distribution. Dense webs did not affect the degree of protection from predation by $N$. womersleyi. Instead, the dense webs might be exploited as a prey-searching cue because this phytoseiid mite follows T. urticae trail including threads (Yano and Osakabe 2009, Shinmen et al. 2010) and their prey preference is strongly affected by spider mite webs (Fruichi et al. 2005). Moreover, the extent of $N$. womersleyi's prey consumption may be due to its ability to cut silken threads while moving within the webs (Shimoda et al. 2010).

In contrast, predation risks by E. sojaensis in uniform distribution and by $N$. womersleyi in contagious distribution were both mitigated in larger area (15-mm squares). This area size depending mitigation was more effective to the predation by E. sojaensis. Denser webs conferred stronger protection

147 from predation by E. sojaensis on 10-mm leaf squares as described above. However, the web density was

148 lower on $15-\mathrm{mm}$ than $10-\mathrm{mm}$ leaf squares in the same distribution because webs were created by the same 149 number of individuals. This demonstrated that predation by E. sojaensis was affected by the combination 150 between web density and size. Interestingly, egg consumption by $N$. womersleyi in contagious distribution 
151 also decreased in 15-mm leaf squares. Although the mechanism of this phenomenon is unknown, web

152 sizes might affect prey searching efficiency of this phytoseiid mite. Therefore, combination between web

153 density and size are likely to affect not only a generalist $E$. sojaensis but also a specialist $N$. wormersleyi.

154 
Furuichi H, Yano S, Takafuji A, Osakabe M (2005) Prey preference of the predatory mite Neoseiulus womersleyi Schicha is determined by spider mite webs. J Appl Entomol 129: 336-339. doi: $10.1111 / j .1439-0418.2005 .00978 . x$

Hislop RG, Prokopy RJ (1981) Mite predator responses to prey and predator-emitted stimuli. J Chem Ecol 7: 895-904. doi: 10.1007/BF00992387

Hoy MA, Smilanick JM (1981) Non-random prey location by the phytoseiid predator Metaseiulus occidentalis: differential responses to several spider-mite species. Entomol Exp Appl 29: 241-253. doi: 10.1111/j.1570-7458.1981.tb03065.x

McMurtry JA, Croft BA (1997) Life-style of phytoseiid mites and their roles in biological control. Annu Rev Entomol 42: 291-321. doi: 10.1146/annurev.ento.42.1.291

McMurtry JA, Johnson HG (1965) Some factors influencing the abundance of the predaceous mite Amblyseius hibisci in southern California (Acarina: Phytoseiidae). Ann Entomol Soc Am 58: 49-56.

McMurtry JA, Scriven GT (1964) Studies on the feeding, reproduction, and development of Amblyseius hibisci (Acarina: Phytoseiidae) in various food substances. Ann Entomol Soc Am 57: 649-655.

Osakabe M (1988) Relationships between food substances and developmental success in Amblyseius sojaensis Ehara (Acarina: Phytoseiidae). Appl Entomol Zool 23: 45-51. doi: 10.1303/aez.23.45

Osakabe Mh, Inoue K, Ashihara W (1986) Feeding, reproduction and development of Amblyseius sojaensis Ehara (Acarina: Phytoseiidae) on two species of spider mites and on tea pollen. Appl Entomol Zool 21: 322-327. doi: 10.1303/aez.21.322

Osakabe Mh, Inoue K, Ashihara W (1987) Effect of Amblyseius sojaensis Ehara (Acarina: Phytoseiidae) as a predator of Panonychus citri (McGregor) and Tetranychus kanzawai Kishida (Acarina: Tetranychidae). Appl Entomol Zool 22: 594-599. doi: 10.1303/aez.22.594 
http://www.lsw.uni-heidelberg.de/users/christlieb/teaching/UKStaSS10/R-refman.pdf.

Sabelis MW, Bakker FM (1992) How predatory mites cope with the web of their tetranychid prey: a functional view on dorsal chaetotaxy in the Phytoseiidae. Exp Appl Acarol 16: 203-225. doi:

Sabelis MW, Vermaat JE, Groeneveld A (1984) Arrestment responses of the predatory mite, Phytoseiulus

Saito Y (1977) Study on the spinning behavior of the spider mite (Acarina: Tetranychidae). I. Method for the quantitative evaluation of the mite webbing, and the relationship between webbing and walking. Jpn J Appl Entomol Zool 21: 27-34. doi: 10.1303/jjaez.21.27

Saito Y (1983) The concept of "life types" in Tetranychinae. An attempt to classify the spinning behavior of Tetranychinae. Acarologia 24: 377-391.

Shimoda T, Kishimoto H, Takabayashi J, Amano H, Dicke M (2009) Comparison of thread-cutting behavior in three specialist predatory mites to cope with complex webs of Tetranychus spider mites. Exp Appl Acarol 47: 111-120. doi: 10.1007/s10493-008-9205-3

Shimoda T, Kishimoto H, Takabayashi J, Amano H, Dicke M (2010) Relationship between the ability to penetrate complex webs of Tetranychus spider mites and the ability of thread-cutting behavior in phytoseiid predatory mites. Biol Control 53: 273-279. doi: 10.1016/j.biocontrol.2010.02.007

Shinmen T, Yano S, Osakabe M (2010) The predatory mite Neoseiulus womersleyi (Acari: Phytoseiidae) follows extracts of trails left by the two-spotted spider mite Tetranychus urticae (Acari: Tetranychidae). 
$210 \quad$ Figure legend

211

212 Fig. 1 Design for uniform (a) and contagious (b) distribution treatment of Tetranychus urticae females (solid circles) over four quadrats separated by wet cotton threads on kidney bean leaf squares (10- or $15-\mathrm{mm}$ square)

215

216 Fig. 2 Predation rates on uniformly and contagiously distributed prey eggs by Euseius sojaensis (A, B) and Neoseiulus womersleyi (C, D) on 15-mm leaf squares (A, C) and 10-mm leaf squares (B, D) for $24 \mathrm{~h}$. Vertical lines at the top of bars represents standard errors (SE). The mean and SE values were calculated with arc sin transformed predation rates of replications. 
(a)

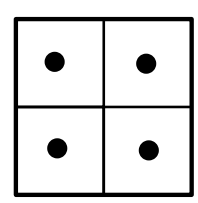

(b)

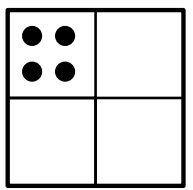

Fig. 1 

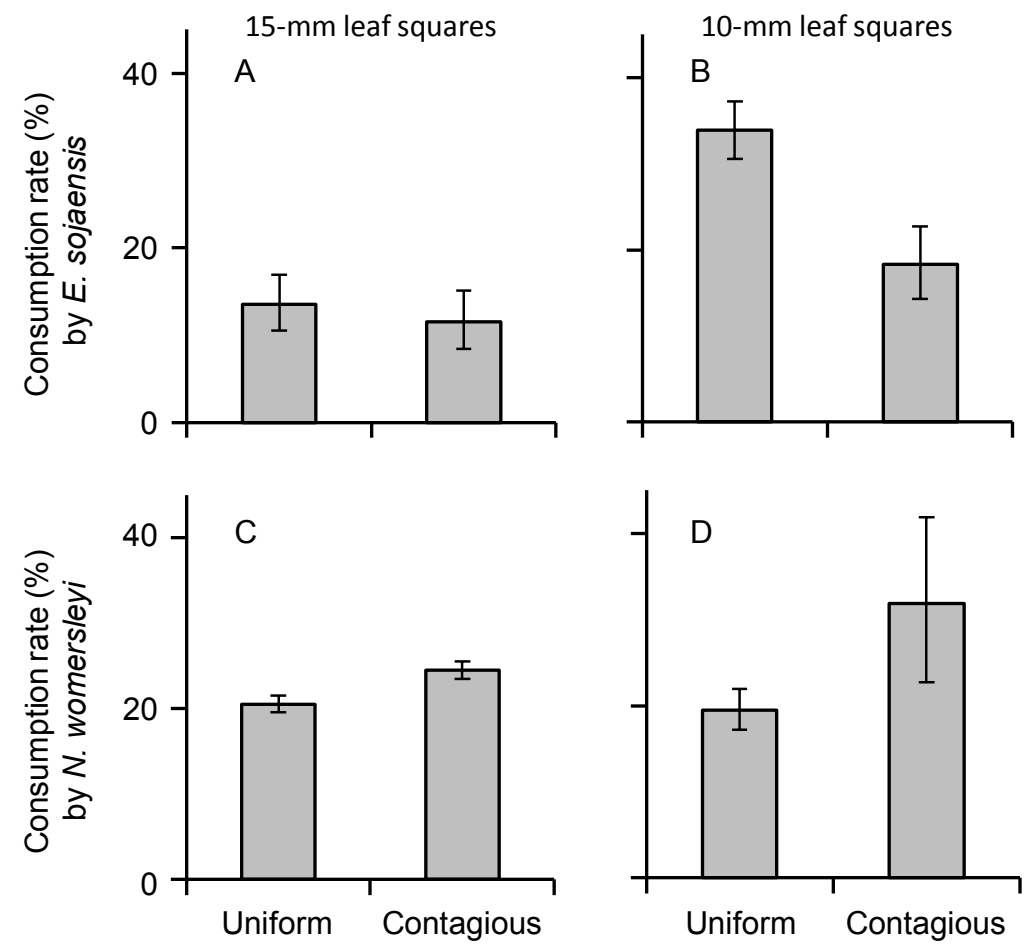

Fig. 2 